\title{
Free Mobility within the Gulf Cooperation Council
}

Zahra Babar

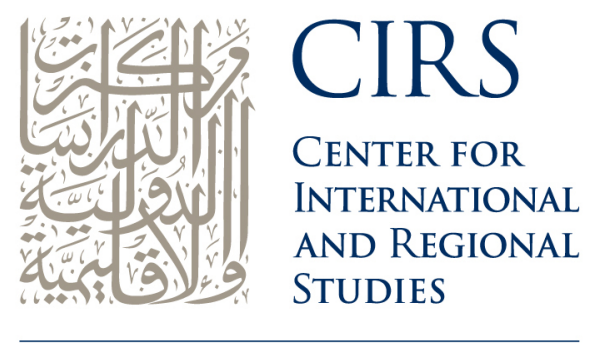

GEORGETOWN UNIVERSITY SCHOOL OF FOREIGN SERVICE IN QATAR

(C) 2011 


\section{Free Mobility within the Gulf Cooperation Council}

Zahra R. Babar

(C) 2011 Center for International and Regional Studies

Georgetown University School of Foreign Service in Qatar

Occasional Paper No. 8

ISSN 2072-5957 


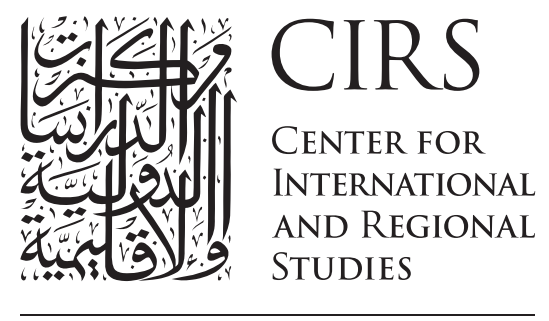

GEORGETOWN UNIVERSITY

SCHOOL OF FOREIGN SERVICE IN QATAR

Established in 2005, the Center for International and Regional Studies at the Georgetown University School of Foreign Service in Qatar is a premier research institute devoted to the academic study of regional and international issues through dialogue and exchange of ideas, research and scholarship, and engagement with national and international scholars, opinion makers, practitioners, and activists.

Guided by the principles of academic excellence, forward vision, and community engagement, the Center's mission revolves around five principal goals:

- To provide a forum for scholarship and research on international and regional affairs

- To encourage in-depth examination and exchange of ideas

- To foster thoughtful dialogue among students, scholars, and practitioners of international affairs

- To facilitate the free flow of ideas and knowledge through publishing the products of its research, sponsoring conferences and seminars, and holding workshops

designed to explore the complexities of the twenty-first century

- To engage in outreach activities with a wide range of local, regional, and international partners.

This publication series is made possible by the generous support of Qatar Foundation for Education, Science and Community Development. 


\section{Free Mobility within the Gulf Cooperation Council}

Zahra R. Babar

Zahra Babar is Project Manager at the Center for International and Regional Studies, Georgetown University School of Foreign Service in Qatar. Previously, she worked in the international aid, community development, and poverty alleviation sectors. She has served with the International Labour Organisation and the United Nations Development Programme. Her current research interests lie in rural development, Gulf migration and labor policies, and GCC regional integration. Babar received her BA in Government from Smith College in Northampton, Massachusetts, and her MA from the School of International Studies at the Jawaharlal Nehru University, New Delhi. 


\begin{abstract}
Stipulations within the formal protocols of the Gulf Cooperation Council (GCC) established free movement of nationals as an essential component of the region's movement towards full economic integration. This paper analyzes the protocols within the broader construct that stresses human emancipation and freedom of mobility as fundamental human rights. Throughout the GCC, states face the peculiar dilemma of supporting full freedom of mobility for citizens while also severely limiting and curtailing the mobility of the dominant, non-national population. This paper questions how normative debates on the freedom of movement apply to the Gulf region and examines the policy and practice of strictly managing the movement of international migrants while at the same time freeing up movement for citizenry. This paper proposes that in the GCC, the regional political economy and the processes of regionalization and globalization have combined to tighten controls over mobility and migration.
\end{abstract}

\title{
Introduction
}

When the Gulf Cooperation Council (GCC) announced on May 10, 2011, that it was considering expanding its membership from the original six founding states to include two new member states of Morocco and Jordan, the response amongst experts on the GCC was largely one of healthy skepticism. ${ }^{1}$ While analysts and scholars paid most attention to the potential security and political dimensions of the proposed expansion, from within the Gulf much of the commentary in the press reflected far more prosaic concerns. The issue that was hotly debated in the press and amongst the public was on the expansion of the rights of free movement for any new entrants to the GCC regionalization project. $^{2}$

Freeing up people's movements across sovereign borders is usually justified either on economic or on moral grounds. The economic grounds for free mobility are based on the need to allow the free flow of labor and capital for economic betterment

\footnotetext{
${ }^{1}$ Siraj Wahab, "Divergent Views Emerge on GCC Expansion Plan,” Arab Nerws, May 12, 2011.

2 Arab News, "GCC Expansion: Admitting New Members like Jordan and Morocco Raises a Plethora of Questions," May 11,2011; James M. Dorsey, "GCC Expansion Threatens to be a Road Pockmarked with Pitfalls," Al-Arabiya, May 12, 2011; Khaleej Times, "GCC's Widening Ambit," May 12, 2011; Abdulrahman Mohammed Al Sultan, "A Definite Downturn in the Gulf Economic Integration," [In Arabic], Al-Arabiya, May 16, 2011; AlTajdeed, "The Economic Feasibility of Morocco Joining the GCC," [In Arabic], May 24, 2011.
} 
of a region. The moral grounds are based on normative concepts of social justice. ${ }^{3}$ Freedom of movement in the Gulf can be examined as both an economic privilege extended to citizens under a regional arrangement, as well as a basic human right.

Within the GCC, policies that privilege regional citizenry and increase their mobility are implemented alongside policies that heavily restrict movements of third-country nationals. Policies which provide special rights of mobility to regional citizenry while excluding others do exist in other areas, such as in the European Union (EU). However, in Europe, expanding free mobility to EU citizens improved ease of trade and travel for non-citizens. Such corresponding changes are not visible in the Gulf. Given that non-nationals make up a large portion of the population in the GCC states, the discrepancies between their mobility and that of nationals seem more glaring. The total population of the six states of the GCC is currently estimated at approximately 39 million, out of which approximately 15 million are non-nationals who are residing and working in the region. ${ }^{4}$

This paper examines the GCC approach towards freedom of movement and how it intersects with regional migration management. Some of the questions addressed are: Why are some people allowed to enter the GCC while others are not? Does simply crossing a GCC border grant a person certain internationally defined rights which the state authority cannot deny? To what extent are limitations imposed on migrants not just to the right to entry, but also to take up an occupation, reside long term, and integrate into the society? And, on what basis do the GCC states argue for greater closure of borders and greater control over entry and participation within their societies?

The particular ways in which migration management and the movement of people have evolved within the GCC is often ascribed to the exceptional circumstances of the development of the region's political economy. While agreeing that there is a great deal of relevance to region-specific circumstances, this paper offers the argument that the way movement is being managed in the GCC is also heavily informed by external and international processes and pressures. In the GCC, the practice of freeing up movement for certain categories of people while simultaneously restricting it for others arises partially out of particular challenges of the regional political economy. It is also a result of normal practices that define the regionalization process and is a response to the pressures of globalization that are impacting the Gulf region.

\footnotetext{
${ }^{3}$ Rainer Baubock, "Citizenship and Free Movement," in Citizenship, Borders, and Human Needs, ed., Roger M. Smith (Philadelphia: University of Pennsylvania Press, 2011).

${ }^{4}$ Badr El Din A. Ibrahim, "Intra-National Labour Mobility Among the Arab Gulf Cooperation Council States in the Context of the Financial Crisis and the Gulf Monetary Union," in Intra-Regional Labour Mobility in the Arab World (Cairo: International Organization for Migration, 2010), 122.
} 


\section{The Gulf Cooperation Council Context: The "Partial Regime” of Free Movement}

Over the course of thirty years, the GCC's process of integration has advanced haltingly, hampered by a lack of decisive leadership, the limitations imposed by protective state sovereignty, and the various competing foreign policy objectives of the different member states. ${ }^{5}$ This integration process has coincided with the evolution of a regional or "khaleeji" identity. ${ }^{6}$ The GCC has evolved both as a functional and administrative body charged with managing the processes of integration, and also as an "imagined entity" that brings with it more profound and nuanced commitment to the concept of a regional identity.

In its current formation, the GCC operates a "partial regime" of free movement, which is one that allows only select categories of residents of a sovereign state to move unimpeded within a broader region, while disallowing other categories of residents from those same rights. The GCC's partial regime extends free mobility across the states' borders as a privilege limited only to the citizens of the six member states. This partial regime expands the notion of a traditional "kbaleeji" identity towards that of full regional economic citizenship for member states' nationals. Available data indicate that this regime of partial free movement has led to only a nominal increase in movement across the borders for the purposes of occupation and employment. ${ }^{7}$ This limited movement is attributed to certain particularities of the region-wide political economy.

The GCC free movement regime is designed as part of the process of fostering regional integration through establishing cooperative policies for trade and economic development. According to the founding documents of the GCC, free movement of nationals among the six member states constitutes a major objective to be implemented over time. ${ }^{8}$ Under the original GCC charter, the long-term

\footnotetext{
${ }^{5}$ Neil Partrick, "The GCC: Gulf State Integration or Leadership Cooperation?" LSE Kuwait Programme on Development, Governance and Globalisation in the Gulf States Research Paper (London: London School of Economic, forthcoming); and Christian Koch, “The GCC as a Regional Security Organization," Konrad Adenaur Stiftung, KAS International Reports, November 2010; Mohamed A1 Khalifa, "Regionalism and the Cooperation Council of Arab Gulf States," February 14, 2011, http://middlingeast.com/2011/02/regionalism/.

${ }^{6}$ For a theoretical definition of "khaleeji identity," see Neil Partrick, "Nationalism in the Gulf States," LSE Kuwait Programme on Development, Governance and Globalisation in the Gulf States Research Paper 5 (London: London School of Economic, 2009), 31.

${ }^{7}$ Ibrahim, "Intra-National Labour Mobility," 110.

${ }^{8}$ In May 1981, the Gulf Cooperation Council's "The Unified Economic Agreement between the Countries of the Gulf Cooperation Council," Chapter II, Article 8, notes that:

The Member States shall agree on executive principles to ensure that each Member State shall grant citizens of all Member States the same treatment as is granted to its own citizens without any discrimination of differentiation in the following fields:

1. Freedom of movement, work and residence.

2. Right of ownership, inheritance and bequest.

3. Freedom of exercising economic activity.

4. Free movement of capital.
} 
goal was for nationals of member states to be given full and complete rights in terms of the right to entry, residence, and employment. ${ }^{9}$ Articles within the GCC Charter, in both the original Unified Economic Agreement of 1981 as well as the new Economic Agreement of 2001, ${ }^{10}$ contain specific provisions allowing full and complete freedom of movement for citizenry, with the over-arching aspiration being to create a GCC-wide labor market.

Under Article Three of the new Economic Agreement signed in December 2001, all GCC natural and legal citizens were given the right to participate in all spheres of economic activity within member-states' territories. The specific rights stated in the agreement of December 2001, include amongst other things: the rights to movement and residence; the right to avail of employment opportunities in both the public and private sectors; access to pension and social security benefits; and engagement in all professions including economic, investment, and service activities. ${ }^{11}$ Currently, no more than 21,000 GCC nationals are employed in a GCC state other their country of origin. ${ }^{12}$

Table 1 provides figures obtained from the Qatar Statistics Authority, and reflects only those non-Qatari GCC nationals who were actively employed in Qatar in $2010 .{ }^{13}$ It does not include those who were resident but unemployed. Given the economic conditions of the region and the variations amongst the six states' economies, as expected, the people that most likely take jobs outside their home countries are predominantly from Oman, Saudi Arabia, and Bahrain. Kuwaitis, Qataris, and Emiratis show a marked disinterest in leaving their countries to take advantage of intra-regional employment opportunities. ${ }^{14}$

The main receiving countries for intra-regional mobility of workers are Kuwait, Qatar, and the UAE. According to the International Organization for Migration (IOM), Saudi Arabia is the only country which both sends its own nationals to work elsewhere within the region and also receives a sizeable number of workers from neighboring countries for employment purposes. Qatar and the UAE are attractive destinations for Saudi nationals seeking intra-regional job opportunities,

\footnotetext{
${ }^{9}$ Ibid.

${ }^{10}$ Ibid.; The Cooperation Council for the Arab States of the Gulf (GCC) Secretariat General, "The Economic Agreement between the GCC States," December 2001, http://www.worldtradelaw.net/fta/agreements/GCC_ FTA.pdf.

${ }^{11}$ Ibid., Chapter II.

12 Ibrahim, "Intra-National Labour Mobility,"122-123.

${ }^{13}$ Detailed annual statistics or other forms of data tracking intra-regional labor mobility in the GCC are hard to come by. This analysis is based on data provided by the Qatar Statistics Authority and Ibrahim, "Intra-National Labour Mobility."

${ }^{14}$ Data collected from the Qatar Statistics Authority.
} 
while Bahrain and Oman are the least likely to attract regional workers. ${ }^{15}$ Given that Saudi Arabia, Oman, and Bahrain have been the three countries in the region most impacted by an increase in the number of young unemployed nationals, ${ }^{16}$ and as a result face the greater unemployment strain, it is reasonable that their citizens would be more likely to take advantage of the freedom of mobility for employment purposes.

Table 1: GCC Nationals Working in Qatar (2010)

\begin{tabular}{|l|l|l|l|}
\hline Nationality & Male & Female & Total \\
\hline Kuwait & 49 & 28 & 77 \\
\hline Bahrain & 469 & 164 & 633 \\
\hline Oman & 3812 & 239 & 4051 \\
\hline Saudi Arabia & 614 & 161 & 775 \\
\hline United Arab Emirates & 177 & 86 & 263 \\
\hline Total & 5121 & 678 & 5799 \\
\hline
\end{tabular}

Source: Data Collected from Qatar Statistics Authority

An analysis of existing GCC documentation, as well as a review of practices that are being implemented by the member-states, demonstrates that the region is adopting a model which supports full mobility amongst its citizenry. However, there are no parallel steps being taken to construct a supranational mechanism for addressing other forms of movement to the region. In similar regional arrangements, such as the European Union, establishing cooperative mechanisms for handling the free movement of citizenry (such as the development of common borders, common visas, and regularized documentation), have had repercussions on the management of other forms of movement. ${ }^{17}$ When the EU instituted a unified approach to managing the internal movement of EU citizens, this necessitated the creation of a regional framework for addressing external movement (migration). ${ }^{18}$ For example in the EU, the opening up of the external border led to concerns over the intake of asylum-seekers and refugees, as member-states had previously implemented independent policies with differing standards of qualification for asylum or refugee

\footnotetext{
${ }^{15}$ Ibrahim, "Intra-National Labour Mobility," 122-123.

${ }^{16}$ Ugo Fasano and Zubair Iqbal, "GCC Countries: From Oil Dependence to Diversification” (Washington: International Monetary Fund, 2003), 11.

${ }^{17}$ Helga Leitner, "Reconfiguring the Spatiality of Power: the Construction of a Supranational Migration Framework for the European Union," Political Geography 16, no. 2 (1997): 123-143.

${ }^{18}$ Ibid., 129-130.
} 
status. Following the Schengen Agreement, the EU states agreed to harmonize standards and qualifications for asylum-seekers across the region. ${ }^{19}$ Such efforts at harmonization for dealing with third-country nationals are not yet present in the existing GCC protocols and agreements.

\section{Open Borders and Migration}

Regionalization projects refine and reconfigure the territorial spaces they concern. A successful regionalization project leads to a reordering and demarcation of the geographical space it will occupy, as well as a new understanding of how that space will be controlled and governed. Issues of a state's sovereignty over managing its territorial boundaries confront the greater interests of a supranational authority charged with creating and managing a larger, shared space. The management of a state's borders, and in turn the management of a region's borders, become areas of focused interaction and intersection between competing interests of sovereign states, supranational regional arrangements, and the international order.

For centuries, people in the Arab world moved across different spatial boundaries for a variety of reasons; to seek employment and economic opportunity, to seek improved skills and education, and to join their families. ${ }^{20}$ Movement as such, was the standard, and restricting it was the exception. ${ }^{21}$ The current climate, both within the GCC region and worldwide, is strikingly different. Human movements across borders are now heavily controlled, and true freedom of mobility exists merely as a notional ideal considered largely unrealistic in terms of practical implementation, and potentially disruptive to the orderly functioning of an international community of nations.

Freedom of mobility is supported in its most liberal interpretation through the framework of the "open borders" theory, ${ }^{22}$ which posits that the ideal human state is one where all nation-states allow their borders to remain open so that those who wish to do so may enter, reside, and work unimpeded. This framework addresses the constraints of an unequal world where countries have developed with differing economic, geological, social, and political resources. ${ }^{23}$ Open border theory is imbedded in notions of democratic justice, and argues that considerations of

\footnotetext{
${ }^{19}$ Ibid., 129-131.

${ }^{20}$ Arab Labor Office, "Inter-Arab Labor Mobility: Opportunities and Aspirations," Report of the Director General of the Arab Labor Office (Amman: Arab Labor Office, 2009), 16.

${ }^{21}$ Enseng Ho, The Graves of Tarim: Genealogy and Mobility Across the Indian Ocean (California: University of California Press, 2006).

${ }^{22}$ Joseph Carens, "Aliens and Citizens: The Case for Open Borders," Review of Politics 49, no. 2 (1987): 251-273

${ }^{23}$ Joseph Carens, "Nationalism and the Exclusion of Immigrants: Lessons from Australian Immigration Policy," in Open Borders? Closed Societies? The Ethical and Political Issues, ed., Mark Gibney (New York: Greenwood Press, 1988), 41-60.
} 
feasibility regarding what states can do should not override the moral compunctions of what they should be striving towards. ${ }^{24}$ This theory is normative in nature and defines the extent to which states open or close their borders as having either a morally indefensible or defensible quality.

Open border advocates argue that borders are manifestly far more than just the physical spaces they occupy. ${ }^{25}$ A sovereign border between two states is actually a complex notion which includes a range of rights and obligations. Both the machinery of a state that controls its border as well as those individuals who traverse it must abide by those rights and obligations. ${ }^{26}$ In the modern age of nation-states, the right to free movement across international borders is generally taken as being untenable, and states have extensive leeway in determining how they wish to control their frontiers and to whom they wish to grant entry rights. However, upon allowing entry to outsiders, states are obliged to treat the entrants in conformity with certain internationally recognized norms of humanitarian behavior. Within the GCC, questions arise not just around the limitations of entry afforded to potential migrants, but also to the treatment meted out to those migrants once they are permitted entry. Over the course of the past few years, GCC states have been hyper-scrutinized for their lack of ability to protect the basic human rights of those migrants who work and reside within their borders.

Open border theory does not presume that the only ideal state is one of complete erasure of sovereign borders, but rather applies normative value to the degree to which states display openness. ${ }^{27}$ In his examination of the tiers of a state's openness, Chandran Kukathas distinguishes between three crucial layers of rights of entry. ${ }^{28}$ At the first tier, the state has the power to determine who has the legal right to enter its sovereign territory. At the second tier, the state has the power to determine which entrants are permitted to participate within the state. Kukathas defines participation as the right to engage in an occupation and reside unimpeded. ${ }^{29}$ At the final tier, the state has the power to determine who has the right to obtain full and complete membership as is granted to citizenry. ${ }^{30}$ Entry, participation, and membership distinguish between the differing levels to which migrants are allowed to play a full role within the society. Membership is equated with citizenship, and

\footnotetext{
${ }^{24}$ Chandran Kukathas, "Expatriatism: The Theory and Practice of Open Borders," in Citizenship, Borders, and Human Needs, ed., Roger M. Smith (Philadelphia: University of Pennsylvania Press, 2011), 340.

${ }^{25}$ Ibid., 327.

${ }^{26}$ Ibid.

${ }^{27}$ Baubock, "Citizenship and Free Movement," 346.

${ }^{28}$ Kukathas, “Expatriatism,” 324-342.

${ }^{29}$ Ibid., 332.

${ }^{30}$ Ibid., 334-337.
} 
comes with privileges such as the access to social welfare, the right to vote, and the right to run for elected office. The Kukathas model provides a normative way of determining the degrees to which a state or region is managing migration, and holds that certain behaviors are more acceptable or "just" than others. Clearly, the first locus of migrants' rights, namely those that cluster around permissions of crossing borders and being allowed to reside and work, are more a concern for Kukathas and other proponents of open borders, rather than paths to full membership and citizenship. This "moral" quality of determining what is acceptable behavior for a state to engage in when managing migration is also reflected in prevailing policy and international norms which place more stress on the liberties of entry and exit, freedom to internal movements, rights to choose an occupation, rights to family unification, and other human and civil liberties which states are expected to grant their entrants as opposed to pathways to citizenship. ${ }^{31}$

Open border theorists have generally applied their analytical framework to higher income, democratically governed, and economically developed regions of the world. Examining the GCC states through this theoretical lens is challenging as these countries are certainly not democratic and liberal in their sociopolitical structure, nor do they present a similar development trajectory as seen in the global north. However, the Gulf region is comprised of rapidly globalizing metropolitan areas which attract scores of foreign residents and function increasingly as global hubs of wealth and economic activity. While none of the states in the region consider themselves to be destination countries for permanent immigration, all of them boast high levels of temporary foreign labor related to their burgeoning development agendas. Data indicate that foreigners comprise $41 \%$ of the total GCC population. ${ }^{32}$ In addition, the GCC is engaged in a regionalization project, which immediately draws attention to territory, borders, and the management of people's movement. These factors make the GCC an interesting case-study for applying the open border framework.

Determining who the recipients of free movement are within a region is often illuminating in understanding the political and economic dimensions of how migration within the region is managed. Without resorting to exceptionalism, there must be due mention made of the atypical labor demographic arrangements that

\footnotetext{
${ }^{31}$ For a more detailed review of the international norms and policies on migration, see Susan Martin, "The Legal and Normative Framework for International Migration," GCIM Policy Analysis and Research Programme Paper (Geneva: Global Commission on International Migration, 2005).

${ }^{32}$ For more comprehensive and detailed data on the labor force and population in the GCC, see Martin BaldwinEdwards "Labour Immigration and Labour Markets in the GCC Countries: National Patterns and Trends," LSE Kuwait Programme on Development, Governance and Globalisation in the Gulf States Research Paper 15 (London: London School of Economics, 2011). In particular, see Table 4, p.11.
} 
are present in the region, and how these impact the framing of freedom of mobility within the Gulf Cooperation Council's policy-making apparatus.

The Gulf labor market reflects a peculiar demographic divide. In proportion to their own nationals, all six of the GCC states host an extraordinarily high number of non-citizen workers, ranging from smaller proportions of highly-skilled "Westerners" to larger numbers of semi- and low-skilled workers hailing primarily from developing countries in South and South-East Asia. Increasing national oil and gas-derived revenues have pushed forward large labor-intensive industrial and construction projects leading directly to the need for a steady supply of cheap, foreign labor. Despite strong statements by national leaders, development planners, and policy-makers in the GCC regarding the need to curb these in-flows, the dependency on foreign labor has certainly not decreased but has consolidated over the past three decades.

The GCC protocols do not address the issue of expanding the free movement regime to include other groups or sub-categories of people present in the region. This is in line with regional sentiments which are not in favor of easing migration or movement for foreigners. National governments express consternation at both the potential security implications of hosting such large populations of extra-regional low-skill migrant workers, as well as the potential social and cultural impact upon citizens who rapidly face becoming, or in some cases already are, the minority within their own countries. ${ }^{33}$

A range of overt and subtle measures of control over migrant laborers' mobility is a part of their lives within the GCC states. Entry and exit into each country is strictly monitored, and intra-regional movement of non-nationals is heavily controlled. ${ }^{34}$ Visa sponsorship arrangements, which require a worker's residency visa to be directly sponsored by an employer, are in place in all but one of the six states. ${ }^{35}$ The visa sponsorship system is rife with potential for employers to engage in exploitative practices which limit the rights of sponsored employees. ${ }^{36}$ One potential area of abuse is the curtailment of migrant workers' rights of mobility. It is regularly reported that employers within the region illegally retain their sponsored

\footnotetext{
33 Andrzej Kapiszweski, Nationals and Expatriates: Population and Labour Dilemmas of the Gulf Cooperation Council States (New York: Ithaca Press, 2001), 6-7.

${ }^{34}$ Ibid., 202-203.

35 Bahrain being the exception as it reformed the previous "kafala" or worker-sponsorship system in May 2009. One of the critical changes under the new policy is that foreign workers are able to transfer their visa sponsorship to a new employer. For further information on reforms to Bahrain's Labour Law, refer to Zahra Babar, "Bahrain's Decision to Repeal the 'Kafala' System," Center for International and Regional Studies Newsletter 9 (Doha: Georgetown University School of Foreign Service in Qatar, 2010), 6.

${ }^{36}$ Andrew Gardner, City of Strangers: Gulf Migration and the Indian Community in Babrain (Ithaca: Cornell University Press, 2010), 29-30 and 58-60.
} 
workers' passports, thus removing from them the ability to leave the country of their own volition. ${ }^{37}$ In addition, sponsored workers must obtain official and written permission from their sponsors before being allowed to exit the country. For highskilled, high-income expatriates in the GCC this may at times just be a formality, but for the majority of the migrant worker population this legal stipulation prevents them from leaving the country for any reason without their employers' authorization and approval. The employer sponsorship system also limits a foreign worker from seeking employment with any company or person other than the original sponsor.

Not only are entry and exit at international points rigorously guarded, but, for certain classes of migrant workers, freedom of movement within the state itself can be problematic. Large numbers of low-wage migrants are often restricted to their "labor camps" or their housing facilities, which tend to be located on the fringes of the cities that they work in. ${ }^{38}$ On their days off, workers may be actively discouraged from entering certain residential or retail parts of the city. While there are no legal limitations or government-enforced curfews that prevent workers from moving about freely, there is a culture of spatial separation which can be overtly or subtly enforced through a variety of measures. Some of the larger shopping and recreational complexes in Qatar, for example, impose "family" hours which last through the weekend, ensuring that male migrant workers may not access these facilities during their days off. ${ }^{39}$

Responding to international concerns over the conditions for migrant workers, most of the GCC states have taken active steps towards developing a more equitable environment for the migrant worker population. In 2009, the government of Bahrain reformed the regulatory system that governs the hiring and retention of expatriate labor, raising the possibility that other GCC governments may follow suit if the experiment succeeds in elevating the standard of living for all workers in the country-citizens and non-citizens alike. ${ }^{40}$

Despite such attempts to implement measures to ensure improved living and working conditions for foreign migrant workers, the GCC governments are still far from developing policies which would ease the movements of workers both into and within the regional bloc. Expanding the existing GCC freedom of mobility regime

\footnotetext{
${ }^{37}$ Philip Martin, "Migration in the Asia Pacific Region: Trends, Factors, Impacts," United Nations Development Programme, Human Development Research Paper 32 (August 2009), 74.

${ }^{38}$ Jane Bristol-Rhys, "Socio-spatial Boundaries in Abu Dhabi," in Migrant Labour in the Persian Gulf, eds. Mehran Kamrava and Zahra Babar (London: Hurst/New York: Columbia University Press, forthcoming).

39 Sarmad Qazi, “Shopping Centres Stick to 'Family-Day' Policy," Gulf Times, October 12, 2008, http://www. gulftimes.com/site/topics/article.asp?cu_no=2\&item_no=247385\&version=1\&template_id=57.

${ }^{40}$ For further information on Bahrain's reformed "Kafala" system, see Habib Toumi, "Bahrain Labour Minister Seeks Support for Scrapping Sponsorship System," Gulf News, May 27, 2009, http://gulfnews.com/news/gulf/ bahrain/bahrain-labour-minister-seeks-support-for-scrapping-sponsorship-system-1.2071.
} 
to include non-national workers is considered anathema to national development planners and is equally unappealing to the regional citizenry. In the GCC agreements there are a few clauses related to liberalizing entry and exit movements of nonnationals, but these are strictly limited for the purpose of facilitating movements for certain trade-related sub-categories such as those engaged in transporting goods across the intra-regional borders. ${ }^{41} \mathrm{It}$ is unlikely that the GCC will be expanding free mobility rights to non-nationals in the foreseeable future.

\section{Regionalism, Globalization, and Citizenship: Tightening GCC Migration}

Regional arrangements have to negotiate a range of competing interests between the member-states and the interests of the supranational entity to which they are a party. ${ }^{42}$ While harmonization of extra-regional migration is considered beneficial to regional arrangements, much of migration policy still remains in the hands of nation-states and not their regional blocs. ${ }^{43}$ Migration is a contested area and states are reluctant to cede too much of their sovereign control over it. It has even been argued by some scholars that managing migration itself becomes a means for the state to build greater legitimacy and authority for itself. As Helene Pellerin has stated:

In other words, countries are using threats to their security posed by migration to adopt initiatives to strengthen their legitimacy and their power. This analysis is interesting, if only because it shows the increasingly common link being made between security and migration, and between borders and migration controls - a link that, according to this logic, is often deliberately fabricated in order to deflect the problem or bolster the authority of the state- or both. ${ }^{44}$

Regardless of the dominance of state sovereignty, regional, bilateral, and multilateral trade arrangements and economic integration regimes are having a profound impact on how migration is being managed. ${ }^{45}$ Most coordinated international and multilateral schemes for managing migration have taken place in regions where considerable progress has been made towards economic integration. ${ }^{46}$

\footnotetext{
41 "The Economic Agreement between the GCC States."

${ }^{42}$ Leitner, "Reconfiguring the Spatiality of Power," 123-143.

${ }^{43}$ Ibid.

${ }^{44}$ Helene Pellerin, "Economic Integration and Security: New Key Factors in Managing International Migration," Institute for Research on Public Policy, Choices 10, no. 6 (2004): 11.

45 Susan Martin, "Towards a Global Migration Regime," Georgetown Journal of International Affairs 1, no. 2 (Summer/Fall, 2000).

${ }^{46}$ Pellerin, "Economic Integration and Security," 6.
} 
Managing regional migration is an intrinsic component of successfully addressing key components of economic integration, such as boosting trade, regionalization of production activities, and creating new relationships between state and non-state economic actors. ${ }^{47}$

Regional arrangements also change the way in which borders operate, and this directly impacts on extra-regional migration. The most visible example of this is in the European Union. Opening up internal borders between member-states of the EU has been an essential part of the EU project. This process of opening up internal borders between EU member-states has gone hand in hand with increasing vigilance and policing of external borders. ${ }^{48}$ The European Union is built around concepts of economic, political, and social integration, and is dedicated to creating a region of "freedom, security, and justice." ${ }^{49}$ Integration led to the opening up of internal borders in Europe, and brought with it fears of a threat to the external borders of the union. ${ }^{50}$ Regionalism may propel states to choose greater flexibility and openness in terms of managing certain borders. Yet, protecting the new borders of the regional arrangement leads to greater rigidity in control over external borders. ${ }^{51}$

In the case of the GCC, the inter-state borders are still rigorously maintained by sovereign states and have not dissolved as they have in the EU. As such, there is no common external border that the GCC states share ownership over or jointly police as each state manages and polices its own borders. While freedom of movement across the sovereign borders for nationals of member-states is implemented, and controls have eased for regional citizenry in terms of the need for obtaining visas, the border controls have not transformed into the sorts of cooperative arrangements that are in place in Europe. Given the current evolutionary state of the GCC bloc and the political dynamics between the six countries that comprise it, the notion of a common external border is still a distant hope. For a common GCC border to come into existence there would have to be heightened levels of political trust amongst the six states, not to mention drastic changes to the regional security architecture, which currently seem very unlikely. Nevertheless, while the GCC does present a very different case from the EU in terms of border management, it does demonstrate

\footnotetext{
${ }^{47}$ Ibid.

${ }^{48}$ Ibid., 11.

${ }^{49}$ The European Union, "Treaty of Amsterdam Amending the Treaty of the European Union, the Treaties Establishing the European Communities and Certain Related Acts," Part 1, Article 1 (1997), http://www. eurotreaties.com/amsterdamtreaty.pdf.

${ }^{50}$ Karolina Szmagalaska-Follis, "What is an Economic Migrant? Europe's New Borders and Politics of Classification" in Citizenship, Borders, and Human Needs, ed. Roger M. Smith (Philadelphia: University of Pennsylvania Press, 2011): 120.

${ }^{51}$ Pellerin, "Economic Integration and Security," 4-24.
} 
elements of the ways in which regionalization has supported and shaped the creation of an "us versus them" approach to managing external border crossings.

Conventional theories of neoliberal economics claim that we live in an increasingly globalized world where both capital and people move easily across international borders. There is, however, a competing body of scholarship which argues that, to the contrary, increasing globalization has in fact created a series of limitations over human mobility. ${ }^{52}$ Sassen ${ }^{53}$ and Shamir's contributions to this literature in particular highlight how the creation of transnational space actually inserts a high degree of specialized controls and exclusions around many people's movements, while allowing a high degree of movement only for a privileged transnational elite. ${ }^{54}$ Globalization itself becomes a realm of both exclusion and inclusion, as it allows certain categories of workers to move with ease, but further restricts those at the lower end of the skill and income scale.

In the Gulf, there are visible signs that globalization is turning migration status into a new marker of privilege. ${ }^{55}$ While there is across-the-board concern over the large presence of foreign workers in the GCC, there are distinctions in terms of how different segments of the foreign population are viewed and treated in terms of rights of entry and participation. In the GCC, globalized cities are developing at breakneck speed and a diverse, multi-class, multi-race population abounds. Here, notions of a universal citizenship come head-to-head to challenge ideas of national sovereignty and state-derived citizenship. The GCC has become one of those "concrete realities" of globalization where there are increasing pressures between universal rights and local fears. ${ }^{56}$ The GCC states' concern over curtailing or limiting opportunities for migration into the region is at least partially informed by these pressures of globalization, and their fears of being turned into amorphous transnational spaces which lack cultural authenticity and sociopolitical integrity.

Citizenship and the ways in which it is constructed is another element which defines how a state or a region manages migration. In fact, amongst the liberal democratic arguments for stricter control over migration and opposition to free movement, it is the citizenship argument which often sounds the loudest and is the most compelling. ${ }^{57}$ The manner in which concepts of citizenship evolve within

\footnotetext{
${ }^{52}$ Ronen Shamir, "Without Borders? Notes on Globalization as a Mobility Regime," Sociological Theory 23, no. 2 (June 2005).

${ }^{53}$ Saskia Sassen, The Global City: New York, London, Tokyo, 2nd ed. (New Jersey: Princeton University Press, 2001).

${ }^{54}$ Shamir, "Without Borders?"

${ }^{55}$ Catherine Dauvergne, Making People Illegal: What Globalization Means for Migration and Law (Cambridge: Cambridge University Press, 2008), 154.

${ }^{56}$ Shamir, "Without Borders?" 214.

${ }^{57}$ Baubock, "Citizenship and Free Movement," 343
} 
a particular society and state has a great impact on the development of migration management. Construction of citizenship results in the creation of markers of eligibility for who can and cannot be a citizen..$^{58}$ As Huysmans suggests in his work on the EU:

In the contemporary domestic and European political context, these policies facilitate the creation of migration as a destabilizing or dangerous challenge to west European societies. It also raises questions about how the development of a common migration policy feeds into the wider politics of belonging that is the struggle over cultural, racial, and socioeconomic criteria for the distribution of rights and duties in a community. ${ }^{59}$

Laws that filter out those who are not marked as eligible create levels of inclusion and exclusion which impact on potential migrants. ${ }^{60}$ Scholars have argued that while the state builds citizenship around norms of inclusion, in reality, the process is just as potent for creating norms of exclusion. ${ }^{61}$

In the Gulf, processes of constructing citizenship have been strongly statedriven and state-instituted over the past four decades. Most of the GCC states were formed a mere four decades ago and had to institute active nationalism projects which are still ongoing. Much of this state-driven nationalism was formed around a normative creation of national citizenship built on stringent criteria of eligibility. In the GCC there are levels of belonging based on who is truly a "genuine" local and thus deserving of citizenship privileges. ${ }^{62}$ Citizenship in the GCC is a subject which cannot be addressed at length in this paper, but suffice to say that it impacts heavily on how processes of migration management have evolved.

An examination of the GCC protocols on freedom of mobility highlight how in many ways the GCC states conform to globally accepted notions of regionalism and economic interdependence. On paper, and through signed documentation, the states of the region are committed to building a more open regional entity. In the GCC, the instruments for regional integration, while offering all the appropriate language for the movement of people within the member-states, deliberately omit any language related to the free movement of people who are not citizens. This is

\footnotetext{
${ }^{58}$ Anh Nga Longva, "Neither Autocracy nor Democracy but Ethnocracy: Citizens, Expatriates, and the SocioPolitical System in Kuwait," in Monarchies and Nations: Globalisation and Identity in the Arab States of the Gulf, eds. Paul Dresch and James Piscatori, (London: I.B. Tauris, 2005), 114-135.

${ }^{59}$ Jef Huysmans, “The European Union and the Securitzation of Migration," Journal of Common Market Studies 38, no. 5 (2000): 753.

${ }^{60}$ Dauvergne, Making People Illegal, 124.

${ }^{61} \mathrm{Ibid}$.

${ }^{62}$ Gardner, City of Strangers, 136-164.
} 
similar to other regional integration processes which also sidestep or ignore the question of the movement of people who are not citizens of member-states. ${ }^{63}$

The partial free movement regime in the GCC exists only to offer mobility rights to citizens, and has so far had no spillover effect to improve mobility conditions for non-citizens. To the contrary, the region is riddled with excessive concern and hyper-scrutiny over non-nationals' movements. This is not an exceptional or unusual case, but is again reflective of a global trend where the framing of migration creates special categories of people who pose a "threat" and so are placed under hyperscrutiny and surveillance.$^{64}$ In the case of the Gulf, these "threatening" people are non-citizen, temporary labor migrants who populate the lower strata of income and skill levels.

\section{GCC Rationale for Limiting Migration}

States articulate assorted reasons for limiting migration and migrants' entry rights. ${ }^{65}$ Much of the debate centers on the threat that migration poses to the internal security, cultural integrity, and economic and political capacity of the state. The following sections provide an overview of some of the key arguments that are presented in the GCC as factors for excluding new entrants.

\section{a) Homogeneity and Protection of Cultural Identity}

Given the skewed demographics present in the Gulf monarchies, a compelling case can be made that GCC societies are facing a real cultural threat by hosting large numbers of non-national, non-Arab workers. This argument has been made for decades and lies at the heart of regional efforts to curb migration flows, as well as efforts to limit migrants' rights to participation and membership in the Gulf states. GCC governments have been unable to put an end to the flows of labor migrants as the demands of the regional labor market make such an option untenable. They have been more successful in ensuring that the migrant community remains transient and unfixed, and that there are no channels towards permanent residency, social integration, and citizenship.

Policies and practices for migration management are consistently presented as being constructed to mitigate the impact of foreigners on local culture, values, traditions, and customs. In GCC policy documents and through public statements by officials and citizens, there is regular mention of the need to protect the cultural

\footnotetext{
${ }^{63}$ Helene Pellerin, "The Cart Before the Horse? The Coordination of Migration Policies in the Americas and these Neoliberal Economic Project of Integration," Review of International Political Economy 6, no. 4 (1999a): 471.

${ }^{64}$ Shamir, "Without Borders?" 204-212.

${ }^{65}$ Kukathas, "Expatriatism," 334.
} 
integrity of the Gulf, as it is perceived as being irrevocably changed and challenged by the continued presence of a foreign workforce. A recent report by the Director General of the Arab Labor Office states:

The Arab world is subject to serious dangers, particularly at the periphery. Waves of migrant labor from everywhere are part of this danger. The demographic composition in some countries has reached a dangerous level which endangers the culture, the norms and future of these countries. Our fear mounts when looking at the history of the formation of some populations and countries, particularly in modern history. These fears deepen when looking at the numbers of non-nationals active in the labor market, the overwhelming numbers of some nationalities, or the establishment of certain incoming cultures. ${ }^{66}$

The homogeneity argument draws on parallels in other regions of the world where demographic shifts in the population structure had long-term consequences for the social and political nature of countries through the erosion of a dominant national character and culture. Examples are given of the heterogeneous mix of countries like Malaysia and Indonesia, where competing linguistic, cultural, and religious traditions vie for dominance. ${ }^{67}$ In the narrow frame of analysis that favors the concept of a single homogenous Gulf Arab identity (and the carefully crafted "national" identity of each GCC state), these hybrid cultural mixes are not viewed as a positive consequence of successfully blended societies, but rather as something to be avoided at all costs. This argument, while prevalent in the GCC today and informing much of the discussion on regional migration management, is certainly neither new nor unique to the Gulf.

The argument to restrict entry of alien "others" in order to protect the development of a stable, culturally authentic state has been made in different countries around the world throughout history. As Carens has proposed in his seminal work analyzing the justification for the "White Australia" policy, threats to homogeneity are just another manifest way in which nationalism is twisted to justify exclusion. ${ }^{68}$ This argument assumes that homogeneity builds a more wedded, closely-knit society where people who share the same values can build a better political and social life. ${ }^{69}$ This assumption holds even though there are a multitude of observable cases, such

\footnotetext{
${ }^{66}$ Arab Labor Office, "Inter-Arab Labor Mobility," 69.

${ }^{67}$ Ibid., 72.

${ }^{68}$ Carens, "Nationalism and the Exclusion of Immigrants," 41-60.

${ }^{69}$ Ibid.
} 
as Malaysia and Singapore, where multi-ethnic and non-homogenous societies are abidingly stable and highly functional.

While states resist the labeling of their actions and policies as racist, arguing instead that they are motivated out of fear of losing common cultural ground, the social construction of the homogeneity argument does appear as discriminatory. ${ }^{70}$ This argument is also difficult to justify due to its lack of economic logic. For small countries which need to build their populations in order to meet their economic and development needs, embracing cultural diversity is often most beneficial. ${ }^{71}$

Through the process of nation-building in the GCC, there has been an idealization of a particular authentic way of life and the creation of a national belief in our culture, our civilization. ${ }^{72}$ This project of creating a focused sense of belonging and nationalism has interacted with the regional patterns of migration to fuel the homogeneity argument. However, it can be argued as Longva convincingly does, that in the Gulf the continuing existence of large numbers of foreigners rather than threatening nationals' identity has, in fact, helped to construct and consolidate it. ${ }^{73}$ The sense shared by nationals that they are ethnically distinct and share a common cultural and social identity is strengthened by the presence of alien others. ${ }^{74}$ The exclusion of foreigners from realms of privilege and participation, and the division of labor between national employers/sponsors and foreign workers enhances the project of identity-building. ${ }^{75}$

\section{b) Social Stability and Security}

Of all the rationales put forward by states as a reason for curtailing immigration flows, the threat posed by migrants to social stability and state security is the most amorphous and difficult to define. It is also the argument that, whilst hardest to legitimately validate, is used most pervasively. In the context of the GCC, the presence of extraordinarily large numbers of non-nationals is consistently presented as a potential threat to the security of the state and a challenge to the public order. These perceived threats to the civic order and security of the state are part of the public mind-set around the discourse of labor migration in the Gulf and inform the ways in which labor migrants are treated by both state and society in the GCC.

\footnotetext{
70 Ibid.

71 Ibid.

72 Clive Holes, "Dialect and National Identity: The Cultural Politics of Self-Representation in Bahraini Musalsalät," in Monarchies and Nations: Globalisation and Identity in the Arab States of the Gulf, eds. Paul Dresch and James Piscatori (London: I.B. Tauris, 2005), 52.

73 Longva, "Neither Autocracy nor Democracy,"114-135.

74 Ibid., 119 and 122.

75 Kapiszweski, Nationals and Expatriates, 22-23.
} 
The literature examining the securitization of migration within the European context provides some interesting parallels and demonstrates that the rationale behind curtailing migration is largely articulated along the same lines no matter which part of the world is being examined. Jef Huysmans' seminal article on the EU points out that securitization of migration in Europe has occurred more as a result of the political processes of securitization brought on through regional integration, rather than as a demonstrated result of actual dangers to civil life that migration has posed. ${ }^{76}$ Within the EU, with the opening up of the internal borders between member-states, third country migration was perceived as a danger to the public order, cultural integrity, and economic stability of the region. As Huysmans argues, with the opening up of the internal EU labor market, a region-wide "security project" was launched, which began to attach itself to a number of processes related to the flow of people and the freedom of mobility. ${ }^{77}$ As in the GCC, in Europe these arguments around the need to restrict and control population flows are steeped in the language of cultural and economic chauvinism.

There are defining practices which are implemented by the state if migration is turned into a problem and if migrants are viewed as a potential danger to society. Security agencies and public figures create a climate of fear by defining migrants as "menacing." The state law-making apparatus and machinery such as ministries of interior and the police begin to pay particular attention to the "threats" migrants may pose. ${ }^{78}$ The aspects of this process that Huysmans discusses regarding the EU are equally visible in the Gulf states. In the GCC, internal security threats posed by migrants are ambiguously defined around the potential harm they pose to the demographic balance and their supposed propensity to crime.

Data which links labor migration in the Gulf to a rise in criminal activity does not exist or is not shared. Sociological research done elsewhere shows that for the large part, immigrants are unusually law-abiding and less likely to get arrested for a criminal act than a natural-born citizen. ${ }^{79}$ Regardless of the lack of empirically-based links between migration and crime, in most countries there is a common perception that migrants (both illegal and legal) are more likely to engage in crime ${ }^{80}$ Anecdotal evidence and the coverage of criminal acts in the print media in the Gulf show a clustering of migrants' "crimes" around a particular set of issues.

\footnotetext{
${ }^{76}$ Huysmans, "The European Union and the Securitization of Migration," 755.

${ }^{77}$ Ibid., 751-777.

${ }^{78}$ Ibid.

79 Tim Wadsworth, "Is Immigration Responsible for the Crime Drop? An Assessment of the Influence of Immigration on Changes in Violent Crime between 1990-2000," Social Science Quarterly 91, no. 2 (2010).

${ }^{80}$ Ibid., 533.
} 
Predominant are the problems of "absconding maids," "absconding workers," acts of petty theft amongst migrants, and other occurrences which certainly cannot pose an overwhelming security threat to the state or its citizens.

Another concern in the Gulf is that foreign workers could pose a political challenge to the state through fomenting public protest or agitating against the regimes in power. In fact, migrant workers to the Gulf have largely remained out of structured political movements, and have seldom taken up coordinated action to challenge the states in which they reside. Very occasionally, workers have held demonstrations or strikes but these have been around employment and wage issues. ${ }^{81}$ Authorities have also expressed concerns that migrants may be affiliated to political or terror organizations in their home countries and will attempt to use the Gulf as a platform for furthering their activities.

Anastassia Tsoukala has pointed out how the regionalization process in Europe led to an emergence of irrational fears in European populations, and led to the securitization of migration. ${ }^{82}$ The consequences of such irrational fears in the Gulf are certainly part of the lived experience of migrants in the GCC today. In the EU as in the Gulf, migration was stated as leading to potential criminal activity, security problems, and urban insecurity-terrorism. ${ }^{83} \mathrm{In}$ sum, in the EU, the process of regionalization led to a prevailing discourse around migration that made it a highly politicized, problematized, and securitized debate. In the Gulf as in Europe, the state is actively engaged in problematizing migration and placing it within the ambit of a political and security discussion. Part of the reason for this lies in the political shape of the regimes that rule the Gulf states. The GCC regimes are autocratic monarchies and as with all authoritarian regimes, internal security missions are heightened. Authoritarian regimes place heavy emphasis on monitoring the domestic political arena in order to eliminate any potential threats. Even in their most benign ruling forms such as in Qatar and the UAE, one cannot forget that none of these are democratic, participatory regimes, and as such they will always remain wedded to heavy policing of the internal realm of the state from where they see their greatest threats arising. Migration is just another sphere where the state's security mission dictates a certain course of action even if in actuality the threat presented is negligible.

Gulf society presents a system of social stratification where both ethnicity and class have a role to play in determining status. ${ }^{84}$ Labor migrants of certain classes and

\footnotetext{
${ }^{81}$ Laurence Louer, “The Political Impact of Labor Migration in Bahrain," City and Society 20, no. 1 (2008): 33.

${ }^{82}$ Anastassia Tsoukala. "Looking at Immigrants as Enemies," in Controlling Frontiers: Free Movement into and within Europe, eds. Didier Bigo and Elspeth Guild (Aldershot: Ashgate, 2005).

${ }^{83}$ Ibid.

${ }^{84}$ Kapiszweski, Nationals and Expatriates, 25-27.
} 
ethnicities are considered to be particularly dangerous to the fabric of GCC society, and deemed to present more of a risk both as potential criminals, and as potential social and political agitators. ${ }^{85}$ This differentiation separates higher-skilled, highincome foreign workers from low-income, lower-skill workers predominantly from Asia and Africa. The presence of the highly-skilled "expatriate" workforce in the Gulf is still presented as a negative but not as a direct threat to the states' security. The origin or national-ethnic background of migrants also elicits different sorts of perceived threats. Non-national Arab workers have traditionally been viewed as a potential politically destabilizing influence by GCC authorities. ${ }^{86}$ Sharing linguistic and cultural affinities with their GCC neighbors, Arab migrants are considered to be more likely to be able to engage with locals and disperse political ideas and ideologies threatening to the state and the status quo. ${ }^{87}$ The fear that Arab migrants might bring infectious political ideologies into the Gulf has no doubt been of heightened concern to local authorities in the context of the 2011 Arab Revolutions. Westerners, conversely, are considered to present more of a cultural or moral threat to the Gulf milieu as opposed to a political one. ${ }^{88}$ Additionally, highly-skilled Western workers are considered to be a threat to the successful advancement of locals within the job market, as they occupy and compete for the jobs which would appeal to Gulf nationals.

The greater fears to public safety and security are usually reserved for those Asian and African workers who occupy the lower rungs of the economic ladder, and who have lower-skill and education levels. This argument on security challenges presented by migrants is thus often presented in racialized and classist terms. The 2009 "Inter-Arab Labor Mobility Report" correlates the presence of low-skilled workers with spikes in incidences of petty crime, the spreading of communicable diseases, and civic disruption through migrants' violent protest. ${ }^{89}$ That these threats to security and civic well-being are not statistically corroborated does not undermine the fact that they are widely accepted as true.

\section{c) Protection of Employment for Nationals}

While the cultural homogeneity and security arguments for limiting migration to the Gulf are difficult to validate, the need to protect employment opportunities for GCC nationals is harder to dismiss. High rates of unemployment are prevalent in

\footnotetext{
${ }^{85}$ Andrzej Kapiszweski, "De-Arabization in the Gulf: Foreign Labor and the Struggle for Local Culture," Georgetown Journal of International Affairs 8, no. 2 (Summer 2007): 83-84.

${ }^{86}$ Longva, "Neither Autocracy nor Democracy," 122-123.

${ }^{87} \mathrm{Ibid}$.

${ }^{88}$ Kapiszweski, "De-Arabization in the Gulf," 87.

${ }^{89}$ Arab Labor Office, "Inter-Arab Labor Mobility," 83-85.
} 
all the GCC states, and expectations are that with a burgeoning youth population, these rates will continue to grow during the coming decades. All six states of the GCC suffer from unemployment rates roughly between 10-15\%, except for Qatar which shows a healthier 3.2\%. ${ }^{90}$

The participation rates of nationals in the GCC economies are low. In Qatar, nationals comprise $17 \%$ of the total labor force, in the UAE the figure is $12 \%$, in Saudi Arabia 28\%, and in Kuwait 18\%. Bahrain with 45\% and Oman with 46\% represent marginally more heartening figures, which are no doubt a reflection of their slightly different economic situations. ${ }^{91}$ Data on levels of unemployment for nationals in each of the six GCC states is not easily accessible, but a recent study indicates that it hovers at $14 \%$ in the UAE and 10\% in Saudi Arabia, while in Kuwait and Qatar the figure stands at 3\%. ${ }^{92}$ Of great concern to local authorities is that the unemployment rates are highest for the under-30 age group. In Saudi Arabia for example, almost $18 \%$ of the population aged 25-29 is unemployed. ${ }^{93}$ Faced with this dilemma of large, unemployed or under-employed national populations, each of the GCC states has over the years committed itself to a "nationalization" project entailing affirmative-action style schemes to increase the employment opportunities for its citizens.

Throughout the Gulf, skills and capacity levels amongst nationals are inadequate in terms of providing a fit for the higher-skill jobs available. The regional labor market is highly segmented along public/private sectors, with limited participation of women, and a predominance of low-skill, low-wage foreign workers occupying jobs which are unattractive to locals. GCC nationals demonstrate a marked preference for employment in the public sector, where superior benefits, higher wages, and shorter working hours are seen as more appealing.

Over the last three decades, the non-national population present in the Gulf region has continued to increase, and foreigners now outnumber nationals in many of the GCC country populations. Nationalization strategies have included the adoption of policies that increase the participation rates amongst GCC citizenry, alongside policies to restrict the number of non-nationals entering the country for work and residence purposes.

Since the early 1990s, governments in the region have rigorously pursued these nationalization plans at the state level, with limited coordination among the various

\footnotetext{
${ }^{90}$ Richard Shediac and Hatem Samman, Meeting the Employment Challenge in the GCC; the Need for Holistic Strategy, Ideation Center Insight, Booz \& Company Report, 2010, http://www.booz.com/media/uploads/ Meeting_the_Employment_Challenge_in_the_GCC.pdf.

${ }^{91}$ Kasim Randeree, "Strategy, Policy and Practice in Nationalisation of Human Capital: "Project Emiratisation," Research and Practice in Human Resource Management 17, no. 1 (2009).

${ }^{92}$ Baldwin-Edwards, "Labour Immigration and Labour Markets in the GCC Countries," 19-20.

${ }^{93}$ Ibid.
} 
GCC member-states. The implementation of GCC-wide freedom of movement, and the subsequent opening up of national markets to all member-states' citizens may make such nationalization of each state's labor force even more of a challenge. Nationalization schemes directed to protect and give preference to a state's citizenry must be carefully managed against the GCC instruments of free mobility which call for a region-wide system of preferential hiring of the nationals of all member-states.

International migration flows into the GCC region are dominated by workers from developing countries coming for purposes of employment in sectors such as domestic work, construction, and other low-skill occupations. The existing assumption is that any intra-regional migration for employment by GCC nationals is dominated by those from the skilled, professional, and business classes. Over the decades it has been a challenge for national governments in the region to cope with meeting the increasing demands for cheap labor for large development programs, while also contending with a low rate of employment amongst their own citizenry. Motivating a large number of nationals to work in lower wage, lower skill occupations is not considered realistic within the current construct of Gulf society, especially in those GCC countries where per capita GDP levels are high (Kuwait, Qatar, the UAE), which means that a continued reliance on imported low-skill labor is inevitable.

The GCC countries are constrained by their dependence on a highly-skilled expatriate labor force active in the private sector, and are also hindered by the limited domestic supply of adequate skills. Across the GCC, there are a limited number of nationals who graduate with scientific or technical qualifications. ${ }^{94}$ There is an excess in supply of professionals/graduates with the same skills competing for the same jobs throughout the region, which curbs the effectiveness of regional labor mobility. Rather than focusing on awareness raising programs to destigmatize the local perception of lower skill occupations, most nationalization schemes focus instead on developing solutions for the replacement of the skilled expatriate class with nationals.

GCC governments have developed mechanisms such as, initiating various quota-based employment schemes in the public sector; incentivizing the private sector to hire nationals on a preferential basis and in some cases subsidizing private sector employers' hiring of nationals; and restricting or limiting work permits and visas for foreign workers. All of these measures to nationalize the regional labor force have had a limited degree of success in terms of effecting real change to the situation of an imbalanced labor market. ${ }^{95}$

\footnotetext{
${ }^{94}$ United Nations Development Programme and Mohammed bin Rashid Al Maktoum Foundation, Arab Knowledge Report 2009: Towards Productive Intercommunication for Knowledge, 2009, 115-123.

${ }^{95}$ Shediac and Samman, "Meeting the Employment Challenge in the GCC," 17.
} 
Whether through coordinated attempts or directly through separate national planning agendas, GCC governments are attempting to address some of the current issues around unemployment in the region. The practice of practically guaranteeing employment in the public sector to local graduates has been revised in most states. Attempts to lessen the difference in wage structure and benefits between the private and public sectors are also being implemented so that private sector employment can be considered more attractive to nationals. Further, establishing employment promotion agencies to assist nationals with job-placement and improve access to information on opportunities in the private sector are being instituted. ${ }^{96}$ Finally, and most crucial of all are the vigorous efforts within the region to bring about reforms to the educational system, and, as a long-term strategy, commit state fiscal resources to human capacity development, education, and training.

\section{d) Rent Preserving Arguments}

Out of all the arguments that underlie the reluctance of the GCC states to change their restrictive policies over migration, the rent preserving rationale is the most valid. Across the globe, limiting entry to new migrants is argued on the basis of rights to welfare security and the state's capacity to provide it. It is believed that the competition over social distribution of goods increases with migration, that the state's capacity to allocate rent is negatively affected, and that in essence migrants are a serious threat to the survival of the socio-economic system of a state. This argument, which is most persuasive in a social welfare state, has even heightened meaning in the context of the Persian Gulf, where the entire contract between state and citizen is based on the obligations and trade-offs of a particular economic bargain, otherwise known as rentierism.

The political economy of the GCC states has developed around their unique position of accounting for about $45 \%$ of global oil reserves. ${ }^{97}$ This immense hydrocarbon wealth has had a socially and economically transformative impact on the states of the region, and has helped to consolidate the traditional political structure of their leadership. Wealth that accrues through oil and gas revenues flows directly to the state, and its disbursement lies largely in the hands of the ruling monarchies. In order to ensure the continued support of their populaces, to obtain their citizens' loyalty and trust, and to ensure state and regime stability, the ruling families in the region have developed extensive mechanisms for sharing their prosperity with their people. In return for forsaking their electoral rights and maintaining their continued support for the rigid structures of state governance, citizens are not required to pay

\footnotetext{
96 Ibid., 2-3.

97 British Petroleum, BP Statistical Review of World Energy June 2010 (London: British Petroleum, 2010 ), 6.
} 
any taxation to their governments, and accrue both direct and indirect forms of state beneficence. This bargain between state and citizen is a common phenomenon across states that operate under such rentier arrangements. ${ }^{98}$

In each of the GCC states, but implemented to different extents, there are all-embracing state-funded systems of support. Government services in many GCC countries are provided free of cost, or else are heavily subsidized. For example, electricity and water are usually provided at no cost to nationals and education and medical treatment are free for citizenry. As a result of such state munificence, the GCC countries tend to accrue high levels of domestic spending. ${ }^{99}$

This unique relationship between the state and citizen in rentier economies is a dominant feature of the GCC region. The state's capacity to transfer or share its rents with its citizenry is vital to ensuring public support to regimes in power. There is a distinct reluctance on the part of the GCC states to actively support inmigration to the region, as this would impact how the rents would be disbursed. The GCC states are already constrained in their capacity to meet the economic needs of their burgeoning populations, and fear that should the economic bargain arrangements be further diluted there would be significant political repercussions. While the regional governments may fear losing their hold over their countries, the nationals, who profit from high per capita incomes and a host of welfare benefits that citizenship confers, are naturally reluctant to share the wealth by admitting new members to the country.

\section{The Potential for GCC Harmonization of Migration Management}

Migration and the management of human mobility across borders have increasingly become realms for international discussion and intervention in the Gulf. International attention has focused on the poor conditions faced by a portion of labor and economic migrants as well the high level of human trafficking that takes place in the region. ${ }^{100}$ The GCC states have been more proactive in coordinating a response to the allegations of human trafficking and less responsive to calls for improving conditions for legal economic migrants.

GCC states have in the past tried to absolve themselves of blame regarding poor living and working conditions for migrants by pointing to the fact that worker sponsorship arrangements allow private actors and employers to play the lead role in managing migration flows into the region. More recently, there has been tacit acknowledgement that the norms of the international migration regime imply that

\footnotetext{
${ }^{98}$ For more detailed information on rentierism, refer to Hazem Beblawi and Giacomo Luciani's The Rentier State (London: Croom Helm, 1987).

${ }^{99}$ Fasano and Iqbal. "GCC Countries: From Oil Dependence to Diversification," 3-4.

${ }^{100}$ US Department of State, Trafficking in Persons Report 2011, http://www.state.gov/g/tip/rls/tiprpt/2011/.
} 
the state can be held accountable even if it does not promote such migration schemes directly. International human rights and migrants' rights organizations are asking for the GCC governments to ensure greater protection for temporary workers. The GCC states are aware that becoming a part of the international effort to cope with issues of migration and human mobility is imperative.

Over the past few years, several of the GCC states have begun to participate in international and regional efforts on migration. In 2005, five of the six GCC countries were invited to be observers to the regional consultative process on migration known as the Colombo Process. ${ }^{101}$ In 2008, all six states became involved in the Abu Dhabi Dialogue, which is another regional process on issues of labor migration to the Gulf from South and South East Asia and which brings together labor sending and labor receiving countries and hopes to address the concerns of both. ${ }^{102}$ In addition, a number of the GCC states are active in the United Nations-sponsored multi-lateral initiative: the Global Forum for Migration and Development. These regional and international efforts on migration offer the GCC states the opportunity to become part of the deliberative processes, rather than merely be recipients of increasing condemnation. To date though, the GCC states have not attempted a harmonized regionally-based approach to developing a migration framework of their own.

As mentioned previously, regionalization projects consist of an ongoing mediating of issues of power and authority between the states and the supranational authority. In terms of migration management it has largely been individual states that have kept sovereign control, except where it has been considered necessary or more efficient for the power and authority to be transferred to the supranational regional entity. ${ }^{103}$ Even in the absence of a defined regionalization process, successful regional arrangements around migration have developed and taken shape. The Puebla Group in Central and North America and the Manila Process in East Asia are both successful examples of this. ${ }^{104}$

In many regional arrangements the push to develop a systematic region-wide approach to migration has occurred as a response to a perceived threat. In the EU context, it was the real or imagined fear of hordes of asylum-seekers, illegal entrants, and trafficked victims pressing on the border of the Schengen that led to greater

\footnotetext{
101 The Colombo Process brings together a number of migrant-sending countries of Asia, and is primarily concerned with ensuring the protection of overseas temporary contractual workers from abusive practices in recruitment and employment. For more on this see: Randall Hansen, "An Assessment of Principal Consultative Processes on Migration," International Organization for Migration Research Series 38 (2010), 64-66.

102 The International Organization for Migration and the Council of Ministers of Labour and Social Affairs of the GCC States, "Ministerial Consultation on Overseas Employment and Contractual Labour for Countries of Origin and Destination in Asia. Final Report,"The Abu Dhabi Dialogue, 21-22 January, 2008. http://www.iom. int/jahia/webdav/shared/shared/mainsite/microsites/rcps/abudhabi/abu_dhabi_dialogue.pdf.

${ }^{103}$ Leitner, "Reconfiguring the Spatiality of Power," 126.

${ }^{104}$ Martin, “Towards a Global Migration Regime."
} 
harmonization efforts. ${ }^{105}$ With the ratification of the Treaty of Amsterdam in 1999, migration matters were pushed to the forefront of the European Union's concerns. ${ }^{106}$ The issue of asylum-seekers was at the core of these concerns and saw the most progress with regards to the level of policy harmonization. Illegal migration was also considered to be central to matters of state security, and was another area where EU harmonization saw progress. In contrast, the management of legal economic migrants was largely left to individual member states. The progress of harmonization in the EU would suggest that legal migration was only of moderate interest to the member states and subsequently the union itself. ${ }^{107}$ States are clearly more willing to develop joint migration policies when there is a sufficient level of concern over the threat posed by certain groups of migrants. As Dauvergne puts it:

In these reactions, the European Union is no different from other prosperous nation-states: the move to aggregate sovereignty at the Union level carries with it a strong interest in those areas that are core to sovereignty. In order for the principles of free movement of workers throughout the Union to be fully realized, the mega-sovereign asserts control over who those workers will be. ${ }^{108}$

The United States offers another interesting example of how the defining narrative on migration serves to set the tone for how migration is managed by the state. If the EU's primary concern has revolved around a unified response to asylumseekers, in the United States the defining issue has been illegal migration. Given the American self-conception of being a nation of immigrants, there is a natural reluctance to identify legal migration flows or asylum seekers as being problematic. In the United States, the focusing of scrutiny on the presence of illegal migrants has pushed forward an agenda which allows the tightening of borders and limitations on all forms of migration. ${ }^{109}$

Regional harmonization of migration policies tend to build on prior bilateral collaborations between states. In Europe, states were reluctant to enter into a regional arrangement for managing migration and preferred to operate bilateral agreements. ${ }^{110}$ The EU played a supportive role and assisted through formulating proposals and suggestions for cooperative action on migration, but the processes were developed

\footnotetext{
105 Pellerin, "The Cart Before the Horse?" 471

${ }^{106}$ Dauvergne, Making People Illegal, 148

${ }^{107}$ Ibid., 147

${ }^{108}$ Ibid.

${ }^{109}$ Dauvergne, Making People Illegal, 164

${ }^{110}$ Leitner, "Reconfiguring the Spatiality of Power," 130
} 
by individual states who sought to collaborate with others. ${ }^{111}$ What the EU case has demonstrated is that the process of harmonization of migration policy has been an unwieldy and sluggish process. Finding political will amongst memberstates to develop common standards has not been easy. Developing a supranational framework and also the necessary institutional mechanisms has been challenging, and it has taken a long time for the EU to achieve levels of success.

While the Gulf Cooperation Council itself has not instituted formal cooperative mechanisms for harmonizing extra-regional migration, one could argue that the existing practices and policies are in essence informally harmonized. Each memberstate has rigid interpretations of who qualifies to be a citizen, limited openings for "naturalization," and thus almost no pathways to citizenship are open to migrants. The "kafala" system has historically been the structural foundation for managing temporary labor migration into all six states, and efforts to abandon or modify it in any one GCC country will certainly cause the remaining five to consider similar steps. Ethnographic scholarship on the region has depicted the lived experiences for labor migrants in the GCC to be similar across the six states. Calls for policy reform and efforts to improve the humanitarian conditions for workers are generally addressed to the bloc rather than to specific states, highlighting the fact that the international community also thinks of migration to the Gulf in regional terms. It is clear that in Gulf there is a level of organic, ad-hoc coordination around migration management, which while not fitting into an easily understood "regionalization" framework, must be taken into account.

GCC states' recent efforts to involve themselves in the international discussion on migration management reflects the fact that they recognize that at least the humanitarian issues on regional migration must be addressed. There is also recognition that economic logic necessitates ongoing migration flows into the region, and if properly managed at both sending and receiving ends could provide beneficial outcomes for all. By this level of engagement, the GCC has also to an extent depoliticized the issue of Gulf migration in the international arena. Moving closer to formally harmonize policy and practice and to establish a regional GCCinitiated approach for managing in-migration would be a positive step. The GCC governments could proactively develop policy and practice to focus on migrants' rights, human rights, and trafficking, and by taking control of the agenda ensure that issues of full integration and pathways to citizenship status remain out of the discussion. In the GCC there is a near absence of any social groups organized around migration issues, ensuring that governments have the capacity to depoliticize the topic in the domestic sphere.

${ }^{111}$ Ibid. 


\section{Conclusion}

As part of its efforts at regional integration, the GCC has adopted a regime of free movement extended to member-states' citizens. The GCC documents demonstrate a fairly liberal interpretation of free movement rights, allowing citizens to move across the six states' borders for a variety of purposes, including residence and employment, and to gain access to a host of social security benefits in any of the member-states. ${ }^{12}$ This regime has so far had no spillover effect to improve mobility conditions for non-citizens.

The GCC region operates tightly regulated and controlled borders. Controls exist at different tier levels so that entry rights, participation rights, and rights to full membership as accorded to citizens are all restricted for non-nationals. There is no GCC common-visa to simplify cross-border movement for legal non-national residents. Participation rights within Gulf societies are contingent on particular visa sponsorship arrangements which tie non-nationals to their sponsoring employers. The structure of the visa sponsorship system limits non-nationals' mobility in terms of changing occupation or workplace, and imposes restrictions on their ability to exit the country. ${ }^{113}$ Pathways to citizenship are almost entirely absent for migrants, as are full membership rights as accorded to nationals.

The GCC states maintain that tightening migration controls have evolved in response to the challenges to the region's social, economic, and political stability. The presence of large numbers of foreigners in the Gulf is articulated as being a threat to domestic security, to cultural homogeneity, to the employment opportunities for nationals, and to the states' ability to spread its wealth amongst its citizenry. None of these arguments is new or unique to the Gulf, but what is most interesting is that within the region migration is constructed as a potential threat to the ruling regimes' capacity to meet their citizens' needs. In the rentier context of a carefully constructed bargain between regimes and their people, an influx of immigrants could indeed be a destabilizing factor.

Migration management and policy development in the Gulf have been informed by these particular characteristics of the region, but they have also been impacted by exogenous challenges. Economic globalization and policies of regionalization have created new geographies of power which confront states' sovereign decisionmaking. ${ }^{114}$ Emerging international human rights regimes also increasingly engage

\footnotetext{
112 “The Unified Economic Agreement;" and “The Economic Agreement between the GCC States.”

${ }^{113}$ Pardis Mahdavi, Gridlock: Labor, Migration, and Human Trafficking in Dubai (Stanford: Stanford University Press, 2011), 49.

114 Saskia Sassen, "Beyond Sovereignty: De-Facto Transnationalism in Immigration Policy," in Worlds on the Move: Globalization, Migration, and Cultural Security, eds. John Friedman and Shalini Randeria (London: I.B. Tauris, 2004), 230.
} 
states' sovereign rights to control migration and movement. ${ }^{115}$ Human mobility and migration become battlefields of competing interests and rights between states, their regional blocs, and the international order.

Regionalization projects, globalization, and citizenship all impact on how migration is managed as they function as realms of both exclusion and inclusion. Defining who lawfully belongs to a country, determining who is legitimately a part of a region, and designating who is a rightful member of the globalized elite all determine the framing of mobility rights within the GCC. In the Gulf, as elsewhere, it is the mobility of those who are the most marginalized that becomes most limited.

${ }^{115}$ Ibid., 229-250. 


\section{BIBLIOGRAPHY}

Al Khalifa, Mohamed. "Regionalism and the Cooperation Council of Arab Gulf States." The Middling East. February 14, 2011. http://middlingeast. com/2011/02/regionalism/.

Al Sultan, Abdulrahman Mohammed. "A Definite Downturn in the Gulf Economic Integration." [In Arabic] Al-Arabiya, May 16, 2011. http://www.alarabiya. net/views/2011/05/16/149251.html.

Al-Tajdeed. "The Economic Feasibility of Morocco Joining the GCC." [In Arabic], May 24, 2011. http://www.attajdid.info/def.asp? codelangue=6\&infoun=666 39\&date_ar=2011/5/24.

Arab Labor Office. "Inter-Arab Labor Mobility: Opportunities and Aspirations." Report of the Director General of the Arab Labor Office. Amman, Jordan. 2009.

Arab Nerws. "GCC Expansion: Admitting New Members like Jordan and Morocco Raises a Plethora of Questions.” May 11, 2011. http://www.arabnews.com/ opinion/editorial/article395980.ece.

Babar, Zahra. "Bahrain's Decision to Repeal the 'Kafala' System." Center for International and Regional Studies, Newsletter 9, Fall 2010. Georgetown University School of Foreign Service in Qatar. http://www12.georgetown. edu/sfs/qatar/cirs/Newsletter9Fall2010.pdf.

Baldwin-Edwards, Martin. "Labour Immigration and Labour Markets in the GCC Countries: National Patterns and Trends." Kuwait Programme on Development, Governance and Globalisation in the Gulf States Research Paper 15. London: London School of Economics, 2011.

Baubock, Rainer. "Citizenship and Free Movement." In Citizenship, Borders, and Human Needs, edited by Roger M. Smith, 343-376. Philadelphia: University of Pennsylvania Press, 2011.

Brenner, Neil. "Global Cities, Global States: Global City Formation and State Territorial Restructuring in Contemporary Europe." Review of International Political Economy 5, no. 1 (1998): 1-37.

Bristol-Rhys,Jane. “Socio-spatial Boundaries in Abu Dhabi." In Migrant Labour in the Persian Gulf, edited by Mehran Kamrava and Zahra Babar, 59-84. London: Hurst/New York: Columbia University Press, forthcoming.

British Petroleum. BP Statistical Review of World Energy June 2010. London: British Petroleum, 2010. http:/www.bp.com/liveassets/bp_internet/globalbp/ globalbp_uk_english/reports_and_publications/statistical_energy_ review_2008/STAGING/local_assets/2010_downloads/statistical_review_ of_world_energy_full_report_2010.pdf. 
Carens, Joseph. "Aliens and Citizens: The Case for Open Borders." Review of Politics 49, no. 2 (1987): 251-273.

. "Nationalism and the Exclusion of Immigrants: Lessons from Australian Immigration Policy." In Open Borders? Closed Societies? The Ethical and Political Issues, edited by Mark Gibney, 41-60. New York: Greenwood Press, 1988.

The Cooperation Council for the Arab States of the Gulf (GCC) Secretariat General. "The Economic Agreement between the GCC States." December 2001. http://library.gcc-sg.org/English/Books/econagree2004.htm.

Dauvergne, Catherine. Making People Illegal: What Globalization Means for Migration and Law. Cambridge: Cambridge University Press, 2008.

Dorsey, James M. "GCC Expansion Threatens to be a Road Pockmarked with Pitfalls.” Al-Arabiya Nerws, May 12, 2011. http://english.alarabiya.net/ articles/2011/05/12/148870.html.

The European Union. "The Treaty of Amsterdam Amending the Treaty of the European Union, the Treaties Establishing the European Communities and Certain Related Acts.” Amsterdam, 1997. http://www.eurotreaties.com/ amsterdamtreaty.pdf.

Friedman, Jonathan, and Shalini Randeria. Worlds on the Move: Globalization, Migration, and Cultural Security. London: I.B. Tauris, 2004.

Gardner, Andrew. City of Strangers: Gulf Migration and the Indian Community in Bahrain. Ithaca: Cornell University Press, 2010.

The Gulf Cooperation Council. "The Unified Economic Agreement between the Countries of the Gulf Cooperation Council." May 1981. http://www. worldtradelaw.net/fta/agreements/gccfta.pdf.

Habib, Toumi. "Bahrain Labour Minister Seeks Support for Scrapping Sponsorship System.” GulfNews, May 27, 2009. http://gulfnews.com/news/gulf/bahrain/ bahrain-labour-minister-seeks-support-for-scrapping-sponsorshipsystem-1.2071.

Hansen, Randall. "An Assessment of Principal Consultative Processes on Migration," IOM Migration Research Series 38. Geneva: International Organization for Migration, 2010.

Ho, Enseng. The Graves of Tarim: Genealogy and Mobility across the Indian Ocean. California: University of California Press, 2006.

Holes, Clive. "Dialect and National Identity: The Cultural Politics of SelfRepresentation in Bahraini Musalsalāt." In Monarchies and Nations: Globalisation and Identity in the Arab States of the Gulf, edited by Paul Dresch and James Piscatori, 52-72. New York: I.B. Tauris, 2005. 
Huysmans, Jef. “The European Union and the Securitization of Migration.” Journal of Common Market Studies 38, no. 5 (2000): 751-757.

Ibrahim, Badr El Din, A. "Intra-National Labour Mobility among the Arab Gulf Cooperation Council States in the Context of the Financial Crisis and the Gulf Monetary Union." In Intra-Regional Labour Mobility in the Arab World, 108-134. Cairo: International Organization for Migration, 2010.

The International Organization for Migration and the Council of Ministers of Labour and Social Affairs of the GCC States. "Ministerial Consultation on Overseas Employment and Contractual Labour for Countries of Origin and Destination in Asia. Final Report.”The Abu Dhabi Dialogue, 21-22 January, 2008. http://www.iom.int/jahia/webdav/shared/shared/mainsite/microsites/ rcps/abudhabi/abu_dhabi_dialogue.pdf.

Kapiszweski, Andrzej. "De-Arabization in the Gulf: Foreign Labor and the Struggle for Local Culture." Georgetown Journal of International Affairs 8, no. 2 (Summer 2007): 81-88.

- Nationals and Expatriates: Population and Labour Dilemma of the Gulf Cooperation Council States. Reading: Ithaca Press/Garnet Publishing Limited, 2001.

Khaleej Times. “GCC's Widening Ambit.” May 12, 2011. http://www.khaleejtimes. com/displayarticle.asp?xfile=data/editorial/2011/May/editorial_May23. $\mathrm{xml} \&$ section=editorial\&col.

Koch, Christian. "The GCC as a Regional Security Organization." Konrad Adenaur Stiftung KAS International Reports. November 2010. http://www.kas.de/ wf/en/33.21076/.

Kukathas, Chandran. "Expatriatism: The Theory and Practice of Open Borders." In Citizenship, Borders, and Human Needs, edited by Roger M. Smith, 324-342. Philadelphia: University of Pennsylvania Press, 2011.

Leitner, Helga. "Reconfiguring the Spatiality of Power: The Construction of a Supranational Migration Framework for the European Union.” Political Geography 16, no. 2 (1997): 123-143.

Longva, Anh Nga. "Neither Autocracy nor Democracy but Ethnocracy: Citizens, Expatriates and the Socio-Political System in Kuwait." In Monarchies and Nations: Globalisation and Identity in the Arab States of the Gulf, edited by Paul Dresch and James Piscatori, 114-135. New York: I.B. Tauris, 2005.

Louer, Laurence. "The Political Impact of Labor Migration in Bahrain." City and Society 20, no. 1 (2008): 32-53.

Mahdavi, Pardis. Gridlock: Labor, Migration, and Human Trafficking in Dubai. Stanford: Stanford University Press, 2011. 
Martin, Susan. “Towards a Global Migration Regime.” Georgetown Journal of International Affairs 1, no. 2 (Summer/Fall, 2000): 119-127.

- "The Legal and Normative Framework for International Migration." GCIM Policy Analysis and Research Programme Paper. Geneva: Global Commission on International Migration, 2005.

Middle East Policy Council. "Amid Turmoil, GCC Extends Invitation to Jordan and Morocco.” May 16, 2011. http://www.mepc.org/amid-turmoil-gcc-extendsinvitation-jordan-and-morocco.

Neil, Partrick. “The GCC: Gulf State Integration or Leadership Cooperation?” Kuwait Programme on Development, Governance and Globalisation in the Gulf States Research Paper. London: London School of Economics, forthcoming. . "Nationalism in the Gulf States," Kuwait Programme on Development, Governance and Globalisation in the Gulf States Research Paper 5. London: London School of Economic, 2009.

Nugee, John, and Paola Subacchi. The Gulf Region: A New Hub of Global Financial Power. London: Chatham House, 2008.

Pellerin, Helene. "Economic Integration and Security: New Key Factors in Managing International Migration." Choices 10, no. 6 (2004).

"The Cart Before the Horse? The Coordination of Migration Policies in the Americas and the Neoliberal Economic Project of Integration.” Review of International Political Economy 6, no. 4 (1999a): 468-493.

—_. "Regionalisation of Migration Policies and its Limits: Europe and North America Compared.” Third World Quarterly 5 (1999b): 995-1011.

Qatar Statistics Authority. 2011. http://www.qsa.gov.qa/eng/index.htm.

Randeree, Kasim. "Strategy, Policy and Practice in Nationalisation of Human Capital: 'Project Emiratisation." Research and Practice in Human Resource Management 17, no. 1 (2009): 71-79.

Sarmad, Qazi. "Shopping Centres Stick to 'Family-Day' Policy." Gulf Times, October 12, 2008. http://www.gulf-times.com/site/topics/article.asp?cu_ no $=2 \&$ item_no $=247385 \&$ version=1\&template_id $=57$.

Sassen, Saskia. "Beyond Sovereignty: De-Facto Transnationalism in Immigration Policy." In Worlds on the Move: Globalization, Migration, and Cultural Security, edited by John Friedman and Shalini Randeria, 229-251. London: I.B. Tauris, 2004.

—_. The Global City: New York, London, Tokyo. 2nd ed. New Jersey: Princeton University Press, 2001.

Shamir, Ronen. "Without Borders? Notes on Globalization as a Mobility Regime." Sociology Theory 23, no. 2 (June 2005): 197-217. 
Shediac, Richard and Hatem Samman. Meeting the Employment Challenge in the GCC; the Need for Holistic Strategy. Ideation Center Insight, Booz \& Co, 2010. http://www.booz.com/media/uploads/Meeting_the_Employment_ Challenge_in_the_GCC.pdf.

Smith, Rogers M. ,ed. Citizenship, Borders, and Human Needs. Philadelphia: University of Pennsylvania Press, 2011.

Sobel, Andrew. Challenges of Globalization: Immigration, Social Welfare, Global Governance. Routledge: London \& New York, 2009.

Szmagalaska-Follis, Karolina. "What is an Economic Migrant? Europe's New Borders and Politics of Classification." In Citizenship, Borders, and Human Needs, edited by Roger M. Smith, 115-131. Philadelphia: University of Pennsylvania Press, 2011.

Tsoukala, Anastassia. "Looking at Immigrants as Enemies." In Controlling Frontiers. Free Movement into and within Europe, edited by Didier Bigo and Elspeth Guild, 161-192. Aldershot: Ashgate, 2005.

Ugo Fasano and Zubair Iqbal. "GCC Countries: From Oil Dependence to Diversification.”Washington: International Monetary Fund, 2003.

United Nations Development Programme and Mohammed bin Rashid Al Maktoum Foundation. Arab Knowledge Report 2009: Towards Productive Intercommunication for Knowledge. 2009. http://www.mbrfoundation.ae/ English/Documents/AKR-2009-En/Forword-Team-Contents.pdf.

US Department of State. Trafficking in Persons Report 2011. 2011. http://www.state. gov/g/tip/rls/tiprpt/2011/.

Wadsworth, Tim. "Is Immigration Responsible for the Crime Drop? An Assessment of the Influence of Immigration on Changes in Violent Crime between 1990-2000.” Social Science Quarterly 91, no. 2 (2010): 531-553.

Wahab, Siraj. "Divergent Views Emerge on GCC Expansion Plan.” Arab Nerws. May 12, 2011. http://www.arabnews.com/saudiarabia/article396251.ece. 


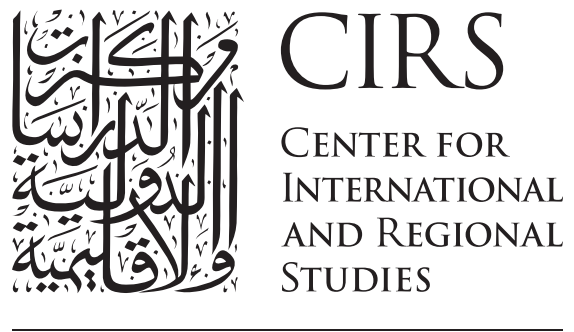

GEORGETOWN UNIVERSITY SCHOOL OF FOREIGN SERVICE IN QATAR

Center for International and Regional Studies Georgetown University School of Foreign Service in Qatar P.O. Box 23689

Doha, Qatar

http://cirs.georgetown.edu

$\mathrm{Tel}+97444578400$

Fax +974 44578401 
